\title{
What Makes a Great Journal Great in the Sciences? Which Came First, the Chicken or the Egg?*
}

\author{
Chia-Lin Chang \\ Department of Applied Economics \\ National Chung Hsing University \\ Taichung, Taiwan \\ Michael McAleer \\ Econometric Institute \\ Erasmus School of Economics \\ Erasmus University Rotterdam \\ and \\ Tinbergen Institute \\ The Netherlands \\ and \\ Institute of Economic Research \\ Kyoto University \\ Japan \\ Les Oxley \\ Department of Economics and Finance \\ University of Canterbury \\ New Zealand
}

EI 2010-75

Revised: December 2010

* The authors wish to thank two referees for very helpful comments and suggestions. For financial support, the first author acknowledges the National Science Council, Taiwan; the second author acknowledges the Australian Research Council, National Science Council, Taiwan, and the Japan Society for the Promotion of Science; and the third author acknowledges the Royal Society of New Zealand, Marsden Fund. 


\begin{abstract}
The paper is concerned with analysing what makes a great journal great in the sciences, based on quantifiable Research Assessment Measures (RAM). Alternative RAM are discussed, with an emphasis on the Thomson Reuters ISI Web of Science database (hereafter ISI). Various ISI RAM that are calculated annually or updated daily are defined and analysed, including the classic 2-year impact factor (2YIF), 5-year impact factor (5YIF), Immediacy (or zero-year impact factor (0YIF)), Eigenfactor, Article Influence, C3PO (Citation Performance Per Paper Online), h-index, Zinfluence, PI-BETA (Papers Ignored - By Even The Authors), Impact Factor Inflation (IFI), and three new RAM, namely Historical Self-citation Threshold Approval Rating (H-STAR), 2 Year Self-citation Threshold Approval Rating (2Y-STAR), and Cited Article Influence (CAI). The RAM data are analysed for the 6 most highly cited journals in 20 highly-varied and well-known ISI categories in the sciences, where the journals are chosen on the basis of 2YIF. The application to these 20 ISI categories could be used as a template for other ISI categories in the sciences and social sciences, and as a benchmark for newer journals in a range of ISI disciplines. In addition to evaluating the 6 most highly cited journals in each of 20 ISI categories, the paper also highlights the similarities and differences in alternative RAM, finds that several RAM capture similar performance characteristics for the most highly cited scientific journals, determines that PI-BETA is not highly correlated with the other RAM, and hence conveys additional information regarding research performance. In order to provide a meta analysis summary of the RAM, which are predominantly ratios, harmonic mean rankings are presented of the 13 RAM for the 6 most highly cited journals in each of the 20 ISI categories. It is shown that emphasizing THE impact factor, specifically the 2-year impact factor, of a journal to the exclusion of other informative RAM can lead to a distorted evaluation of journal performance and influence on different disciplines, especially in view of inflated journal self citations.
\end{abstract}

Keywords: Research Assessment Measures (RAM), impact factors, Immediacy, Eigenfactor, Article Influence, Cited Article Influence, h-index, C3PO, Zinfluence, PI-BETA, IFI, HSTAR, 2Y-STAR.

JEL Classifications: C43, C10, Z0. 


\title{
Be not afraid of greatness: \\ some are born great, some achieve greatness, and some have greatness thrust upon them.
}

\author{
Malvolio, Twelfth Night \\ William Shakespeare (1564-1616)
}

\section{Introduction}

\begin{abstract}
Although there is a multitude of contradictory biblical, bibliographical, conceptual, Darwinian, definitional, evolutionary, genetic, grammatical, literary, logical, logistical, mathematical, paleontological, paradoxical, philosophical, processional, and theoretical possibilities associated with the perennial question as to which came first, the chicken or the egg, the same question may also be asked in the context of which came first, the great paper or the great journal in which the paper was published. In short, does the quality, somehow defined, of a journal define the quality of a paper, the reverse, or both?
\end{abstract}

High quality published research is fundamental to all individual researchers in the sciences and social sciences. In this regard, research assessment rankings are essential to evaluate the research performance of individuals and the quality of academic journals. The perceived research performance of individual researchers can be crucial for hiring, firing, tenure and promotion decisions. In the absence of suitable information regarding the perceived quality of research output, the quality of a journal has frequently been used as a proxy for the research quality of an academic paper. Publishing in a prestigious journal can provide great stimulus to moving in the right direction along the career path. In this context, how might quality and prestige be defined quantitatively?

The perceived quality of a journal would be seen by many as an inappropriate and misleading proxy for the inherently latent quality of a paper, especially in the early years of publication. The quality and prestige of a leading journal is based on the quality of published papers. However, a leading journal cannot be an accurate reflection of the quality of a recently published paper, especially when the paper has received few if any citations to date, and all 
the more so if a paper is yet to appear in the pages of a journal (for more on this, see Seglen (1997), who finds that citation rates of papers determine the impact factor of journals, and not vice-versa).

It should be borne in mind that the acceptance of a paper for publication in a journal is typically based on one or more of the Editor, Co-editor, Associate Editor, and 1-3 referees. This small group of experts decides the rejection rate prior to publication. It is well known that even experts can and do make mistakes. The rejection rate of a journal after publication depends on the profession. For this reason, it is essential to know the proportion of published papers that is ignored by the profession, and by even the authors. The large market of researchers worldwide is less prone to making errors regarding the quality of academic research papers than a small group of experts at any journal, great or otherwise. This is the reason Chang et al. (2010) proposed PI-BETA (Papers Ignored - By Even The Authors) as a RAM to capture such mistakes after publication.

Type I and Type II errors arise in any decision made under uncertainty, namely bad papers that are accepted for publication in a journal, and good papers that are rejected. As noted in Chang et al. (2010): "Great papers appear in great journals [and] All great journals publish great papers [but] Not all papers in great journals are great." Papers that have zero citations after a number of years are clearly errors, whether or not they appear in great journals. Editors, Co-editors, Associate Editors and referees may not care about bad papers that are accepted for publication in a journal, but PI-BETA allows the reader to decide whether decisions to publish papers have been prescient.

For purposes of evaluating the research performance of individual researchers and the quality of academic journals, some Research Assessment Measures (RAM) are subscription based, while others can be downloaded free of charge from the Internet. A leading high quality database for generating RAM is the Thomson Reuters ISI Web of Science database (hereafter ISI). This paper examines the importance of ranking RAM, emphasizes the importance of RAM as viable rankings criteria, highlights the usefulness of existing RAM from Thomson Reuters ISI (hereafter ISI RAM), and evaluates the usefulness of three new RAM.

The empirical analysis of RAM presented in this paper concentrates on the 6 most highly cited journals in 20 ISI categories in the sciences. Garfield (1972) developed citation analysis 
as a tool in evaluating the impact of journals. Although the question posed in the title of the paper refers to greatness, virtually all RAM measures are based on recent citations, that is, within the past two or five years. Citations capture scientific impact, visibility, performance, influence, utility and prestige, which should not be confused with scientific excellence, quality, content, importance, innovation, scientific progress, intellectual property, industrial transfers, and social benefits, among others. There is no substitute for peer review in evaluating the scientific quality of an individual paper, and hence all of the papers published in journals. Greatness of a journal may be hard to define quantitatively, but the question in the title of the paper still needs to be asked.

As citations form the foundations of most bibliometric measures, the application of a meta analysis of several RAM to the journals in these 20 ISI categories could be used as a template for other ISI categories in both the sciences and social sciences, and as a benchmark for newer journals in a range of ISI disciplines. In addition to evaluating the most highly cited journals in these 20 ISI categories, the paper examines the impact of journal self citations on journal performance, compares alternative RAM, and highlights the similarities and differences of alternative RAM. It is shown that emphasizing THE impact factor, specifically the 2-year impact factor, of a journal to the exclusion of other useful and illuminating RAM, can lead to a distorted evaluation of journal performance and influence on the professions, especially in view of inflated journal self citations.

The plan of the remainder of the paper is as follows. Section 2 presents some key bibliometric research. Section 3 discusses alternative RAM, with an emphasis on the Thomson Reuters ISI Web of Science database. Alternative RAM that are calculated annually or updated daily are defined and analysed, including the 2-year impact factor (2YIF), both with and without self citations, 5-year impact factor (5YIF), Immediacy (or zero-year impact factor (0YIF)), Eigenfactor score, Article Influence, C3PO (Citation Performance Per Paper Online), h-index, Zinfluence, PI-BETA (Papers Ignored - By Even The Authors), Selfcitation Approval Rating (STAR), both historical and 2-year, Impact Factor Inflation (IFI), and Cited Article Influence (CAI). Section 4 discusses and analyses ISI RAM data for the 6 most highly cited journals in each of 20 ISI categories in the sciences, and presents harmonic mean rankings of the 13 RAM. Section 5 summarizes the outcomes and discusses some future uses of RAM. 


\section{Some Key Bibliometrics Research}

The bibliometric literature on RAM is extensive, but it is worth mentioning some key papers relating to the limitations of the journal impact factor, type I and type II errors in journal decision processes, alternative measures of the h-index, and correlations across different RAM that are based on citations. All but one of these papers have been published in recent years.

Seglen (1997) argues that the impact factor of journals should not be used to evaluate research of individual researchers. In evaluating the relationship between the impact factor of a journal and the citation rate of an article, the author finds that journal impact factors are not statistically representative of the journal articles of an individual. Moreover, there is a difference in article citation rates in that articles in the more cited half of articles in a journal are much more highly cited than those in the less cited half. Seglen (1997) also presents arguments that the computation of a journal impact factor is fundamentally flawed. Interestingly, article citation rates are found to determine the journal impact factor, but not the reverse.

Following this theme, Kermarrec et al. (2007) try to determine what bibliometric indicators actually measure. They evaluate alternative citations sources, bibliometric indicators, misuse and unintended effects of such indicators, and costs of indicators and their implications. The authors conclude that impact and quality are not equivalent, that several bibliometric indicators should be used, that comparisons across disciplines should not be made, that bibliometric indicators should be complemented by other measures, especially peer assessment, for purposes of evaluating research output by individuals and research teams, and that the temptation to rely on automated evaluation based on bibliometric indicators should be resisted.

Neuhaus et al. (2009) also discuss the limitations of the journal impact factor, with an emphasis on chemistry. The critical issue investigated is whether a single measure is appropriate for characterizing journal impact in a multidisciplinary setting. The findings, which extend beyond chemistry, show that the information contained in the citation index is inappropriate for purposes of comparison, and that the length of the citation window and the 
thematic focus of a journal has a significant effect on the journal impact factor. Overall, the authors find that the journal impact factor is insufficient for characterizing the significance and performance of multidisciplinary journals.

Each of these three papers emphasizes that impact is not equivalent to quality, and that more than one RAM, specifically the journal impact factor, should be considered in evaluating a journal. In short, relying solely on the journal impact factor, regardless of the citation window, is bound to be misleading, so more than one RAM should be used. It is difficult to argue with such a conclusion.

Bornmann and Daniel (2009) consider type I and type II errors in editorial decisions in chemistry, specifically a citation analysis for papers that were accepted by the journal, or rejected by the journal and subsequently published elsewhere. It was found that $15 \%$ of the papers had a type I error, namely accepted papers that performed no better than the average rejected paper, and that $15 \%$ of the papers were affected by type II error, whereby rejected papers performed at least as well as the average accepted paper. Thus, the authors were able to calculate the extent to which the future success of published papers could be over- or under-estimated on the basis of editorial decisions.

Two papers provide a systematic analysis of the h-index as a bibliometric measure of publication activity and citation impact. Schubert and Glanzel (2007) test a theoretical model of Hirsch-type indexes on the number of publications and the average citation rate. The deterministic model relates the h-index to the cube root of the product of the number of publications and the square of the journal impact factor. The empirical model suggests that the relationship is linear and the weight is approximately 0.75 , with a high goodness-of-fit. Thus, the data suggest that the h-index is highly correlated with a nonlinear function of the number of publications and the impact factor, such that the RAM are related.

Bornmann et al. (2008) compare the h-index and eight important variations thereof for purposes of evaluating research output and the journal impact factor. In particular, it is intended to evaluate whether any of the variations of the h-index have an incremental contribute to evaluating research performance. One variation of the h-index describes the most productive core of research output and the papers in that core, whereas the other variation of the h-index describes the impact of the papers in the core. Using a logistic 
regression, it was found that peer assessments could be predicted more accurately using the impact of the productive core than the quantity of the output in the core.

In the final paper in this section, Elkins et al. (2010) calculate the pairwise correlations between the ISI journal impact factor and three other journal citation indexes, namely the Eigenfactor ${ }^{\mathrm{TM}}$ metrics article influence score, SCImago's journal rank index, and the Scopus trend line index. The correlations of the six pairings of four indexes were found to be strong to very strong (lying between 0.61 and 0.89 ), thereby providing evidence of convergent validity, that is, closely related average journal citations per article. From a purely statistical perspective, it does not seem to matter which index might be used to capture the impact of citations, despite substantial differences in constructing the different citations measures.

\section{Research Assessment Measures (RAM)}

Several Research Assessment Measures (RAM) are available for recording research performance. Some of these measures are subscription based, while others are downloadable free from the Internet. Alternative sources of RAM are discussed briefly below.

\subsection{Thomson Reuters ISI Web of Science}

The Thomson Reuters ISI Web of Science database is available to subscribers. Although books and non-ISI journals are not included in the database, a wide range of leading journals is included in the ISI database for an extended period. According to ISI Web of Science (2010): "Authoritative, multidisciplinary content covers over 10,000 of the highest impact journals worldwide, including Open Access journals and over 110,000 conference proceedings." The broad range of RAM may readily be modified to measure research productivity and citations impact of academic researchers and ISI recognised journals.

Alternative excellent databases include the Social Science Research Network (SSRN) database, which includes a very large number of working papers and publications in the social sciences (including economics, finance, accounting, marketing and management, among others), the Research Papers in Economics (RePEc) database for economics (which excludes self citations by both individual researchers and journals in compiling all the RAM 
statistics), the Scopus subscription-based database, and free Internet databases, such as Google Scholar. Each of these databases has their strengths and limitations (see Kermarrec et al. (2007) for a very useful analysis of the limitations of several citation-based bibliometric indicators). However, ISI would seem to establish the 'gold standard' database for purposes of generating RAM for journals and individual researchers in a wide range of disciplines in the sciences and social sciences for an extended period.

\subsection{Definitions of ISI RAM}

The existing and new RAM presented below are useful descriptive statistics, and are based on ratios or differences. They are not based on statistical or econometric models, and require no estimation, but rather calculation. Nine RAM, namely 2YIF, 2YIF*, 5YIF, Immediacy, IFI, C3PO, PI-BETA, Article Influence, Cited Article Influence, are based on ratios, two RAM, namely H-STAR and 2Y-STAR, are based on differences, and two RAM, namely h-index and Eigenfactor, are descriptive. In view of the convincing suggestions arising from several papers in Section 2 that more than one RAM, specifically the journal impact factor, should be considered in evaluating a journal, we consider 13 RAM in total and a robust method of combining them.

\subsubsection{Annual RAM}

With two exceptions, namely the Eigenfactor and Article Influence scores, existing RAM is reported separately for sciences and social sciences, and may be computed annually or updated daily. Annual RAM are calculated for a Journal Citations Reports (JCR) calendar year, which is the year before the annual RAM are released (usually in mid-year). For the JCR year 2008, the annual RAM were released in mid-2009.

The following RAM are defined in Table 1, and are discussed briefly below:

\section{(1) 2-year impact factor (2YIF):}

The classic 2-year impact factor (2YIF) of an ISI journal is typically referred to as "THE impact factor", and is calculated annually. The choice of two years as a citation window for measuring journal impact would seem to be arbitrary. As is widely known, impact factors are journal impact factors, and are intended to evaluate journals rather than papers published in 
journals. The range of 2 YIF is from zero upwards. For the JCR year 2008, total citations are for papers published in 2006 and 2007. [It is worth noting that there can be confusion regarding the definition and meaning of impact factors. For example, Bergstrom and West (2008, p. 1850), the developers of Eigenfactor"TM metrics, incorrectly state that "Impact factor is essentially a measure of the average number of citations that a journal's articles receive over the two calendar years following publication.]

\section{(2) 2-year impact factor without self citations (2YIF*):}

ISI reports a "2-year impact factor without journal self citations", that is, excluding citations to a journal where a citing paper is published. As this impact factor is not widely used, we will refer to this RAM measure as $2 \mathrm{YIF}^{*}$. The range of $2 \mathrm{YIF}^{*}$ is from zero upwards.

\section{(3) 5-year impact factor (5YIF):}

The 5-year impact factor (5YIF) of an ISI journal is similar to 2YIF, and is calculated annually. The choice of five years as an alternative citation window for measuring journal impact would seem to be arbitrary. The range of $5 \mathrm{YIF}$ is from zero upwards. For the JCR year 2008, total citations are for papers published in 2003, 2004, 2005, 2006 and 2007.

\section{(4) Immediacy:}

Immediacy is effectively a zero-year impact factor (OYIF) of an ISI journal, and is calculated annually. The choice of the present year as a citation window for measuring journal impact would seem to be arbitrary, and would be more useful for some disciplines than others. The range of Immediacy is from zero upwards. For the JCR year 2008, total citations are for papers published in 2008 .

\section{(5) Eigenfactor score:}

The Eigenfactor score (Bergstrom (2007), Bergstrom, West and Wiseman (2008)) is a modified 5YIF that is intended to capture "prestige", and is calculated annually. For a JCR year, the Eigenfactor algorithm (see www.eigenfactor.org/methods.htm) ranks journals according to the amount of time researchers are logged on to a journal's website. To state the obvious, the Eigenfactor is unable to check how much time researchers spend reading hard copies of journals. The range of Eigenfactor is from zero upwards.

\section{(6) Article Influence:}


Article Influence is a standardized Eigenfactor score, is calculated annually, and measures the relative importance or "influence" of an ISI journal on a per-article basis. The range of Article Influence is from zero upwards.

\section{(7) IFI:}

The ratio IFI $=2 \mathrm{YIF} / 2 \mathrm{YIF}^{*}$ is intended to capture how journal self citations inflate the impact factor of a journal. The minimum value for IFI is 1 , with any value above the minimum capturing the effect of journal self citations on the 2-year impact factor. Thus, the range of IFI is from one upwards.

\subsubsection{Two New RAM (computed annually)}

ISI has recognized the inflation in journal self citations by calculating an impact factor that excludes such self citations, and provides data on journal self citations, both historically and for the preceding two years, in calculating 2YIF (though not 5YIF or Immediacy). In this paper, we suggest two new RAM, as follows:

\section{(8a) H-STAR:}

For the Historical Self-citation Threshold Approval Rating (H-STAR), if HJS = historical journal self-citations (in per cent), the difference between citations in other journals and journal self-citations is $\mathrm{H}-\mathrm{STAR}=(100$-HJS $)-$ HJS $=100-2$ (HJS). Thus, if HJS $=0$ (outstanding), 25, 50 or 100 (unthinkable), H-STAR $=100,50,0$ and -100 , respectively. The range of H-STAR is $[-100,100]$.

\section{(8b) 2Y-STAR:}

For the 2 Year Self-citation Threshold Approval Rating (2Y-STAR), if 2YJS = 2 year journal self-citations (in per cent), the difference between citations in other journals and journal self-citations is $2 \mathrm{Y}-\mathrm{STAR}=(100-2 \mathrm{YJS})-2 \mathrm{YJS}=100-2(2 \mathrm{YJS})$. Thus, if $2 \mathrm{YJS}=0$ (outstanding), 25, 50 or 100 (unthinkable), 2Y-STAR $=100,50,0$ and -100 , respectively. The range of 2 Y-STAR is $[-100,100]$.

\subsubsection{Daily Updated RAM}


Other RAM are updated daily, and are reported for a given day in the current year rather than for a JCR year.

\section{(9) C3PO:}

ISI reports the mean number of citations for an ISI journal, namely total citations up to a given day divided by the number of papers published in an ISI journal up to the same day, as the "average" number of citations. In order to distinguish the mean from the median and mode as an "average", Chang et al. (2010) use C3PO (Citation Performance Per Paper Online) of an ISI journal on any given day as the mean. The range of $\mathrm{C} 3 \mathrm{PO}$ is from zero upwards. [Note: C3PO should not be confused with C-3PO, the Star Wars android.]

\section{(10) h-index:}

The h-index (Hirsch, 2005)) was proposed to assess the scientific research productivity and citations impact of individual researchers. Although the h-index can also be calculated for journals, it should be interpreted as assessing the impact of highly cited publications in ISI journals. The h-index includes journal self-citations. The range of the h-index is from zero upwards.

\section{(11) PI-BETA:}

A recently suggested ISI RAM measures the proportion of papers in a journal that has never been cited, which is, in effect, a rejection rate after journal publication. Chang et al. (2010) argue that lack of citations of a published paper, especially over an extended period, may detract from the quality of a journal by exposing: (i) what might be considered as incorrect decisions by the editorial board of a journal; and (ii) the lost opportunities of papers that might have been cited had they not been rejected by the journal. For this reason, Chang et al. (2010) define a paper with Zinfluence as "zero influence, based on zero citations in ISI journals", which can be measured by PI-BETA (= Papers Ignored - By Even The Authors). As PI-BETA is given as a fraction, the range is $[0,1]$.

\subsubsection{A New RAM (updated daily)}

\section{(12) Cited Article Influence (CAI):}

Article Influence is intended to measure the average influence of an article across the sciences and social sciences. As an article that is not cited cannot have influence, a more 
plausible measure of the influence of cited articles is Cited Article Influence (CAI). If PI$\mathrm{BETA}=0, \mathrm{CAI}$ would be equivalent to the Article Influence; if PI-BETA $=1$, then CAI $=0$. As Article Influence is calculated annually, whereas PI-BETA is updated daily, CAI would also be updated daily. The range of Cited Article Influence is from zero upwards.

\subsection{Caveats regarding ISI RAM}

The inclusion of all articles in an ISI journal includes papers, abstracts and book reviews, and possibly even conference reviews, software reports, and letters to the editor. Although RAM can be very useful and informative, it is worth emphasizing that it is not entirely free of measurement error. The following caveats should be considered in using RAM (for further details see, for example, Garfield (1972) and Kermarrec et al. (2007)).

ISI citations can be affected by misspellings of the titles of journals and names of authors, incorrect use of author's initials, and incorrect year of publication, volume number, and/or the starting page number of the ISI journal article. Only those citations that are correct in every respect will be attributed correctly to the cited author. Otherwise, any error will lead to a different citation, such that the total citations of a publication for a particular author will be too low. Any missing in action (MIA) citations are the responsibility of the citing author(s), and not of ISI. It is virtually impossible to check for spelling variations on the names of any authors as the possibilities are endless.

Further caveats relate to the date of downloading ISI RAM, as daily updates will change the h-index, C3PO, PI-BETA, STAR and CAI scores. The time period for downloading ISI RAM should also be noted as all the ISI RAM will change annually. For journals such as Nature and Science, as well as several journals in the medical sciences, which have a high frequency of publication and publish a large number of articles, the default option for daily ISI RAM updates would seem to vary between two and four years. Otherwise, the threshold of 10,000 articles for purposes of obtaining daily ISI RAM updates will be exceeded. Shortening the period of analysis will necessarily reduce the h-index of a journal, increase C3PO and decrease PI-BETA, but will not bias the analysis against the inherent quality of any journal.

\section{Analysis of ISI RAM Data}


$\mu \varepsilon \underline{t} \alpha \beta \beta \lambda \eta ́ ~ \rho o ́ v \underline{t} \omega v \gamma \lambda v \kappa v ́$

[a change is always nice]

\section{Euripides Orestes, 234}

\section{Variety's the very spice of life, That gives it all its flavour.}

\section{William Cowper (1731-1800)}

The primary purpose of this section is to evaluate, using 13 RAM, the 6 most highly cited journals in each of 20 highly-varied and well-known ISI categories in the sciences. The journals are chosen on the basis of the most widely-used ISI RAM, namely the 2-year impact factor (2YIF). The 6 most highly cited journals, as well as the total number of journals in each of the 20 ISI categories (in parentheses), are given in Table 2. As there were 8 overlapping journals across the 20 categories, namely Advanced Materials, Annual Review of Earth and Planetary Sciences, Communications on Pure and Applied Mathematics, Global Change Biology, Environmental Health Perspectives, International Journal of Nonlinear Sciences and Numerical Simulation, Mathematical Programming, and Nano Letters, there are 112 distinct journals.

Only articles from ISI Web of Science are included in the citation data. Data for all journals were downloaded from ISI on 4 June 2010 for all citations for 1988-2010, so that citations are counted from 1988 for all papers published in an ISI journal since 1988. As ISI does not provide daily updates for more than 10,000 articles for purposes of calculating the h-index, C3PO, PI-BETA and CAI, the initial years of several journals were chosen so that no journal had more than 10,000 articles.

Of the 112 distinct journals, 21 had the period of analysis truncated from 1988-2010 in order to be able to provide the daily updated ISI RAM. These 22 journals are as follows (with starting year given in parentheses): Astrophysical Journal (2007), FASEB Journal (2007), Angewandte Chemie - International Edition (2005), Environmental Health Perspectives 
(1989), New England Journal of Medicine (2005), JAMA - Journal of the American Medical Association (2004), Lancet (2005), Annals of Internal Medicine (1994), British Medical Journal (2008), Nature (2007), Science (2007), Proceedings of the National Academy of Sciences of the United States of America (2009), Physical Review Letters (2008), American Journal of Psychiatry (1995), Biological Psychiatry (2001), American Journal of Epidemiology (2000), Epidemiology (1997), American Journal of Transplantation (2005), British Journal of Surgery (1996), Journal of Neurology, Neurosurgery and Psychiatry (1994), and Journal of Comparative Neurology (1989).

As of JCR 2008, the numbers of journals in these 20 categories range from 42 journals in Multidisciplinary Sciences (a category that includes Nature, Science, and Proceedings of the National Academy of Sciences of the United States of America) to 221 journals in Neurosciences. The 13 RAM for the 6 most highly cited journals in each of the 20 ISI categories in the sciences are given in Table 2. The number of articles in the 112 distinct journals has a substantial range, from hundreds up to almost 10,000 articles for the period 1988-2010. As each of the 13 RAM can vary substantially by journal and category, each of the 20 ISI categories will be summarized as High, Medium or Low according for the following RAM:

Group 1: 2YIF, 2YIF*, 5YIF, Immediacy, h-index and C3PO;

Group 2: IFI, H-STAR, 2y-STAR;

Group 3: PI-BETA;

Group 4: Eigenfactor, Article Influence, Cited Article Influence (CAI).

For Group 1, namely performances according to 2YIF, 2YIF*, 5YIF, Immediacy, h-index and C3PO, Mathematics, Operations Research \& Management, Statistics \& Probability, and Zoology are Low; Astronomy and Astrophysics, Chemistry - Multidisciplinary, Materials Sciences - Multidisciplinary, Medicine - General \& Internal, Multidisciplinary Sciences, Neurosciences, and Physics - Multidisciplinary are High; and the remaining 9 ISI categories are Medium.

In Group 2, namely IFI, H-STAR, 2Y-STAR, Astronomy and Astrophysics, Engineering Multidisciplinary, Geosciences - Multidisciplinary, and Operations Research \& Management are High; Chemistry - Multidisciplinary, Ecology, Statistics \& Probability, Surgery, and 
Zoology are Medium; and the remaining 11 ISI categories are Low. Journal self citation in some categories can be quite high, such as inflated 2YIF by a factor of 1.459 in Astronomy and Astrophysics, 1.290 in Ecology, 4.246 in Engineering - Multidisciplinary, 2.362 in Geosciences - Multidisciplinary, and 1.338 in Operations Research \& Management. H-STAR and 2Y-STAR can be as low as 46 and 38 in Astronomy and Astrophysics, 68 an 56 in Ecology, -38 and -52 in Engineering - Multidisciplinary, 14 and -14 in Geosciences Multidisciplinary, 52 and 50 in Operations Research \& Management, and 44 and 68 in Statistics \& Probability.

PI-BETA in Group 3 vary markedly, both within and across ISI categories. Only Zoology has a Low PI-BETA, with only one journal having $12.50 \%$ of papers that have never been cited. Astronomy and Astrophysics, and Chemistry - Multidisciplinary are Medium, with 13.04\% and $18.12 \%$ of papers in one journal in each category never having been cited. For the remaining 17 categories in the High classification, the highest percentages of any journal with papers that have never been cited are: $83.77 \%$ in Biology, $44.21 \%$ in Ecology, $33.55 \%$ in Engineering - Multidisciplinary, 69.27\% in Environmental Sciences, 30.12\% in Geosciences - Multidisciplinary, $97.31 \%$ in Materials Sciences - Multidisciplinary, $76.78 \%$ in Mathematics, $41.70 \%$ in Mathematics - Applied, 72.82\% in Medicine - General \& Internal, $68.48 \%$ in Multidisciplinary Sciences, $57.79 \%$ in Neurosciences, $39.60 \%$ in Operations Research \& Management, 38.98\% in Physics - Multidisciplinary, 67.35\% in Psychiatry, $78.31 \%$ in Public, Environmental \& Occupational Health, 46.34\% in Statistics \& Probability, and $75.61 \%$ in Surgery. It should be emphasized that these are not atypical as in 3 (3) categories, 6 of 6 (5 of 6) highly cited journals have extremely high PI-BETA.

In Group 4, namely Eigenfactor score, Article Influence, Cited Article Influence (CAI), there are 4 ISI categories that are High, specifically Astronomy and Astrophysics, Medicine General \& Internal, Neurosciences, and Operations Research \& Management. The 6 categories in the Medium range are Biology, Chemistry - Multidisciplinary, Ecology, Geosciences - Multidisciplinary, Materials Sciences - Multidisciplinary, and Physics Multidisciplinary. The remaining 10 categories are in the Low category. Given the great variations in PI-BETA, the rankings according to Article Influence and CAI can vary substantially. 
The correlations between pairs of alternative ISI RAM have long been a source of discussion and debate in the scientific community. Fersht (2009) showed that there was a very strong positive correlation between Eigenfactor and the total number of journal citations. Such strong correlations are not entirely surprising, and would seem to capture the size effect of journals, with the total number of publications and total citations typically being positively and highly correlated.

The simple correlations for the 13 RAM for the 112 highly cited distinct journals in 20 ISI categories in the sciences are given in Table 3. The 6 pairs of RAM for which the correlations exceed 0.9 are (2YIF, 2YIF*), (2YIF, 5YIF), (2YIF*, 5YIF), (5YIF, Article Influence), (Article Influence, CAI), and (H-STAR, 2Y-STAR). Six other pairs of RAM for which the simple correlations lie just below 0.9 (in absolute value) are (2YIF, Immediacy), (2YIF, Article Influence), (2YIF*, Immediacy), (2YIF*, Article Influence), (IFI, H-STAR), and (IFI, 2Y-STAR). PI-BETA is the only RAM that has very low simple correlations with each of the other 12 RAM scores, so that PI-BETA conveys additional information to what is contained in the 12 other RAM scores.

As the aggregation of the RAM across the 20 ISI categories might be masking some differences across the categories, the simple correlations (which are not reported here due to space limitations) have been calculated separately for each of the 20 ISI categories. Bearing in mind that there are only 6 journals in each category for purposes of calculating the correlations, similar comments as in Table 2 generally apply to each of the 20 separate categories, although the simple correlations vary according to RAM and ISI category. The high correlations are least frequent for Environmental Sciences, Materials Sciences Multidisciplinary, and Mathematics.

It remains to be seen whether an emphasis on THE impact factor, specifically the 2-year impact factor, of a journal to the exclusion of other informative RAM, can lead to a distorted evaluation of journal performance and influence on the profession. In order to provide a meta analysis summary of the RAM, which are predominantly ratios, the overall rankings of the leading 6 journals in each of the 20 ISI categories across the 13 RAM are calculated using the harmonic mean. The harmonic mean rankings are reported in the final column in Table 2. 
Of the 20 ISI categories, only 2 categories had no changes in rank orders, namely Biology and Statistics \& Probability. Regarding the highest ranked journal in each category according to 2 YIF, 14 of the 20 categories had unchanged highest rankings according to the harmonic mean, with only Astronomy and Astrophysics, Ecology, Geosciences - Multidisciplinary, Mathematics - Applied, Operations Research \& Management, and Zoology, having their respective most highly cited journals changing in rank order. As Article Influence is a modification of 5YIF, it is interesting to note that 16 of 20 categories had the same journal ranked number 1 according to both RAM, with Ecology, Environmental Sciences, Mathematics, and Statistics \& Probability being the only exceptions to the expected outcome. Interesting movements include Operations Research \& Management, which had 5 changes in rank order, including one journal falling by 5 places; Surgery had 5 changes in ranks, including 3 journals each changing their ranks by 3 positions; and Engineering Multidisciplinary had one journal falling by 4 positions.

These empirical findings can be connected to the key bibliometric references in Section 2. They support the view of Seglen (1997) and Neuhaus et al. (2009), among many others, that the impact factor (specifically, 2YIF, though similar comments would also apply to 5YIF, and possibly also 2YIF*), should not be used uncritically. We would temper such a recommendation that impact factors should not be used uncritically, as they do provide descriptive statistics that can be informative. As one such measure of 13 RAM that are used to provide a harmonic mean, impact factors should certainly not be discarded. The empirical results are also consistent with the discussion in Kermarrec et al. (2007), who suggest that several bibliometric indicators should be used. We would concur, such that this paper has used 13 such bibliometric indicators.

PI-BETA supports the consideration of Bornmann and Daniel (2009) by explicitly recognising the existence of errors in editorial decisions by reporting those papers that have zero citations. Schubert and Glanzel (2007) suggested that the h-index is highly correlated with the impact factor, and Bornmann et al. (2008) compared nine important variations of the h-index to evaluate research output and the journal impact factor. In Table 3, the h-index is shown to have correlations in excess of 0.5 with six other RAM (including 0.541 and 0.591 with 2 YIF and 5YIF, respectively), which shows there is indeed overlap among the different RAM, especially citation rates. Elkins et al. (2010) found a strong correlation between the journal impact factor (specifically, 2YIF) and the Eigenfactor ${ }^{\mathrm{TM}}$ metrics article influence 
score. Table 3 shows that Article Influence indeed has a high correlation of 0.888 with 2YIF, and an even higher correlation of 0.936 with 5YIF. Overall, the empirical findings of this paper are entirely consistent with the key bibliometric references cited above.

\section{Conclusion}

The paper discussed alternative Research Assessment Measures (RAM), with an emphasis on the Thomson Reuters ISI Web of Science (hereafter ISI) database. Alternative RAM that are calculated annually or updated daily were defined and analysed, including the classic 2-year impact factor (2YIF), with and without journal self citations, 5-year impact factor (5YIF), Immediacy (or zero-year impact factor (0YIF)), Eigenfactor, Article Influence, h-index, C3PO, Zinfluence, PI-BETA, Impact Factor Inflation (IFI), and three new RAM, namely Historical Self-citation Threshold Approval Rating (H-STAR), 2 Year Self-citation Threshold Approval Rating (2Y-STAR), and Cited Article Influence (CAI).

The RAM data were analysed for the 6 most highly cited journals in each of 20 highly-varied and well-known ISI categories in the sciences. As citations form the foundations of most bibliometric measures, the application of a meta analysis of RAM to the journals in these 20 ISI categories could be used as a template for other ISI categories in both the sciences and social sciences, and as a benchmark for newer journals in a range of ISI disciplines.

In addition to evaluating high quality research in the 6 most highly cited journals in each of 20 ISI categories, with 112 Distinct journals, the paper also compared alternative RAM, highlighted the similarities and differences in alternative RAM, found that several RAM captured similar performance characteristics for the most highly cited journals, determined

that PI-BETA was not highly correlated with the other RAM, and hence conveyed additional information. Harmonic mean rankings of the 13 RAM for the 6 most highly cited journals in the 20 ISI categories were also presented. It was shown that emphasizing THE impact factor, specifically the 2-year impact factor, of a journal to the exclusion of other useful and illuminating RAM, could lead to a distorted evaluation of journal performance and influence on the profession, especially in view of inflated journal self citations. 
What is the road map for existing and future RAM, most of which are based on citations? Likely future uses of RAM include using RAM for research assessment exercises, and as input into academic appointments and promotions. Conundrums such as whether or not it is better to publish in a journal with: (i) high rather than low two-year impact factor (with and without self citations); (ii) high rather than low five-year impact factor; (iii) high rather than low Immediacy; (iv) high rather than low h-index; (v) high rather than low C3PO; (vi) low rather than high PI-BETA; (vii) high rather than low Eigenfactor score; (viii) high rather than low Article Influence; (ix) high rather than low STAR (both historical and 2-year); (x) low rather than high IFI; and (xi) high rather than low CAI; can also be analysed critically, as such choices will likely increase the probability of being highly cited. 


\section{References}

Bergstrom C. (2007), Eigenfactor: Measuring the value and prestige of scholarly journals, C\&RL News, 68, 314-316.

Bergstrom, C. and J.D. West (2008), Assessing citations with Eigenfactor ${ }^{\mathrm{TM}}$ metrics, Neurology, 2008(71), 1850-1851.

Bergstrom, C.T., J.D. West and M.A. Wiseman (2008), The Eigenfactor ${ }^{\mathrm{TM}}$ metrics, Journal of Neuroscience, 28(45), 11433-11434 (November 5, 2008).

Bornmann, L. and H.-D. Daniel (2009), Extent of type I and type II errors in editorial decisions: A case study on Angewandte Chemie International Edition, Journal of Informetrics, 3(4), 348-352.

Bornmann, L., R. Mutz and H.-D. Daniel (2008), Are there better indices for evaluation purposes than the $\mathrm{h}$ index? A comparison of nine different variants of the $\mathrm{h}$ index using data from biomedicine, Journal of the American Society for Information Science and Technology, 59(5), 830-837.

Chang, C.-L., M. McAleer and L. Oxley (2010), Great expectatrics: Great papers, great journals, great econometrics. Available at SSRN: http://ssrn.com/abstract=1618167.

Elkins, M.R., C.G. Maher, R.D. Herbert, A.M. Moseley and C. Sherrington (2010), Correlation between the journal impact factor and three other journal citation indices, Scientometrics, 85, 81-93.

Fersht, A. (2009), The most influential journals: Impact factor and Eigenfactor, Proceedings of the National Academy of Sciences of the United States of America, 106(17), 6883-6884 (April 28, 2009).

Garfield, E. (1972), Citation analysis as a tool in journal evaluation, Science, 178(4060), 471479 (November 3, 1972).

Hirsch, J.E. (2005), An index to quantify an individual's scientific research output, Proceedings of the National Academy of Sciences of the United States of America, 102(46), 16569-16572 (November 15, 2005).

ISI Web of Science (2010), Journal Citation Reports, Essential Science Indicators, Thomson Reuters ISI.

Kermarrec, A.-M., E. Faou, J.-P. Merlet, P. Robert and L. Segoufin (2007), What do bibliometric indicators measure?, INRIA Evaluation Committee Analysis Document, Available at http://www.inria.fr/inria/organigramme/documents/ce_indicateurs_en.pdf.

Neuhaus, C., W. Marx and H.-D. Daniel (2009), The publication and citation impact profiles of Angewandte Chemie and the Journal of the American Chemical Society based on the sections of Chemical Abstracts: A case study on the limitations of the journal impact factor, Journal of the American Society for Information Science and Technology, 60(1), 176-183. 
Schubert, A. and W. Glanzel (2007), A systematic analysis of Hirsch-type indices for journals, Journal of Informetrics, 1(3), 179-184.

Seglen, P.O. (1997), Why the impact factor of journals should not be used for evaluating research, BMJ: British Medical Journal, 314 (7079), 498-502. 
Table 1

Definitions of Research Assessment Measures (RAM)

\begin{tabular}{|c|c|}
\hline RAM & Definition \\
\hline $2 \mathrm{YIF}$ & $\begin{array}{l}\text { Total citations in a year to papers published in a journal in the } \\
\text { previous } 2 \text { years / Total papers published in a journal in the } \\
\text { previous } 2 \text { years }\end{array}$ \\
\hline $2 \mathrm{YIF}^{*}$ & 2YIF without journal self citations \\
\hline $5 \mathrm{YIF}$ & $\begin{array}{l}\text { Total citations in a year to papers published in a journal in the } \\
\text { previous } 5 \text { years / Total papers published in a journal in the } \\
\text { previous } 5 \text { years }\end{array}$ \\
\hline $\begin{array}{l}\text { IFI } \\
\text { (Impact Factor Inflation) }\end{array}$ & $2 \mathrm{YIF} / 2 \mathrm{YIF}^{*}$ \\
\hline h-index & Each of $\mathrm{h}$ papers is cited at least $\mathrm{h}$ times \\
\hline $\begin{array}{l}\text { C3PO } \\
\text { (Citation Performance Per } \\
\text { Paper Online) }\end{array}$ & Total citations to a journal / Total papers published in a journal \\
\hline $\begin{array}{l}\text { PI-BETA } \\
\text { (Papers Ignored - By Even } \\
\text { The Authors) }\end{array}$ & $\begin{array}{l}\text { Number of papers in a journal with zero citations / Total papers } \\
\text { published in a journal }\end{array}$ \\
\hline Eigenfactor & $\begin{array}{l}\text { Modified 5YIF that ranks journals according to the amount of time } \\
\text { researchers are logged on to a journal's website }\end{array}$ \\
\hline $\begin{array}{l}\text { Immediacy } \\
\text { (or } 0 \text { YIF) }\end{array}$ & $\begin{array}{l}\text { Total citations in a year to papers published in a journal in the same } \\
\text { year / Total papers published in a journal in the same year }\end{array}$ \\
\hline Article Influence & $\begin{array}{l}\text { Eigenfactor score / Fraction of all ISI articles published by a } \\
\text { journal }\end{array}$ \\
\hline Cited Article Influence & (1 - PI-BETA)(Article Influence) \\
\hline $\begin{array}{l}\text { H-STAR } \\
\text { (Historical - Self-citation } \\
\text { Threshold Approval Rating) }\end{array}$ & $\begin{array}{l}\text { H-STAR }=100-2(\mathrm{HJS}) \text {, where HJS }=\text { historical journal self- } \\
\text { citations }\end{array}$ \\
\hline $\begin{array}{l}\text { 2Y-STAR } \\
\text { (2Year- Self-citation } \\
\text { Threshold Approval Rating) }\end{array}$ & $\begin{array}{l}2 \mathrm{Y}-\mathrm{STAR}=100-2(2 \mathrm{YJS}), \text { where } 2 \mathrm{YJS}=\text { journal self-citations in } \\
\text { the previous } 2 \text { years }\end{array}$ \\
\hline
\end{tabular}


Table 2

Research Assessment Measures (RAM) for 6 Journals in Each of 20 ISI Categories

\begin{tabular}{|c|c|c|c|c|c|c|c|c|c|c|c|c|c|c|}
\hline Journal & 2YIF & 2YIF* & 5YIF & IFI & $\begin{array}{c}\text { h- } \\
\text { index }\end{array}$ & C3PO & $\begin{array}{c}\text { PI- } \\
\text { BETA }\end{array}$ & Eigenfactor & Immediacy & $\begin{array}{c}\text { Article } \\
\text { Influence }\end{array}$ & CAI & $\begin{array}{c}\text { H- } \\
\text { STAR }\end{array}$ & $\begin{array}{l}\text { 2Y- } \\
\text { STAR }\end{array}$ & $\begin{array}{c}\text { Harmonic } \\
\text { Mean }\end{array}$ \\
\hline \multicolumn{15}{|c|}{ Astronomy and Astrophysics (48) } \\
\hline $\begin{array}{l}\text { Annual Review of } \\
\text { Astronomy and } \\
\text { Astrophysics } \\
\end{array}$ & 25.828 & 25.609 & 24.370 & 1.009 & 138 & 166.76 & 0.0653 & 0.02337 & 0.692 & 14.444 & 13.500 & 100 & 100 & 3 \\
\hline $\begin{array}{l}\text { Astrophysical Journal } \\
\text { Supplement Series }\end{array}$ & 13.990 & 13.366 & 12.119 & 1.047 & 175 & 55.59 & 0.0475 & 0.11166 & 2.638 & 6.836 & 6.511 & 92 & 92 & 2 \\
\hline $\begin{array}{l}\text { Astronomy and } \\
\text { Astrophysics Review }\end{array}$ & 7.500 & 7.300 & 8.833 & 1.027 & 45 & 58.39 & 0.0667 & 0.00190 & 1.750 & 4.758 & 4.441 & 96 & 96 & 1 \\
\hline $\begin{array}{l}\text { Journal of Cosmology } \\
\text { and Astroparticle } \\
\text { Physics }\end{array}$ & 6.389 & 4.690 & 6.026 & 1.362 & 53 & 12.36 & 0.1251 & 0.04452 & 1.847 & 2.267 & 1.983 & 52 & 48 & 4 \\
\hline $\begin{array}{l}\text { Annual Review of } \\
\text { Earth and Planetary } \\
\text { Sciences }\end{array}$ & 6.364 & 6.295 & 9.040 & 1.011 & 80 & 54.19 & 0.0713 & 0.01443 & 1.368 & 6.447 & 5.988 & 100 & 98 & 6 \\
\hline Astrophysical Journal & 6.331 & 4.338 & 5.743 & 1.459 & 72 & 8.90 & 0.1812 & 0.54472 & 2.083 & 1.874 & 1.534 & 46 & 38 & 5 \\
\hline \multicolumn{15}{|l|}{ Biology (72) } \\
\hline Plos Biology & 12.683 & 12.500 & 14.662 & 1.015 & 103 & 30.13 & 0.1172 & 0.15465 & 2.184 & 8.744 & 7.719 & 98 & 98 & 1 \\
\hline Biological Reviews & 8.755 & 8.660 & 9.343 & 1.011 & 63 & 42.22 & 0.1013 & 0.01203 & 0.379 & 4.050 & 3.640 & 100 & 98 & 2 \\
\hline FASEB Journal & 7.049 & 6.943 & 7.128 & 1.015 & 33 & 1.31 & 0.8377 & 0.12998 & 1.388 & 2.614 & 0.424 & 100 & 98 & 3 \\
\hline $\begin{array}{l}\text { Quarterly Review of } \\
\text { Biology }\end{array}$ & 6.688 & 6.688 & 9.023 & 1.000 & 63 & 43.97 & 0.4378 & 0.00381 & 0.143 & 3.994 & 2.245 & 100 & 100 & 4 \\
\hline $\begin{array}{l}\text { Philosophical } \\
\text { Transactions of the } \\
\text { Royal Society B- } \\
\text { Biological Sciences }\end{array}$ & 5.556 & 5.414 & 6.293 & 1.026 & 74 & 17.49 & 0.0768 & 0.05692 & 2.800 & 2.993 & 2.763 & 92 & 96 & 5 \\
\hline Bioessays & 5.316 & 5.203 & 5.509 & 1.022 & 143 & 35.85 & 0.1136 & 0.04010 & 0.813 & 2.603 & 2.307 & 98 & 96 & 6 \\
\hline
\end{tabular}




\begin{tabular}{|c|c|c|c|c|c|c|c|c|c|c|c|c|c|c|}
\hline Journal & 2YIF & 2YIF* & $5 Y I F$ & IFI & $\begin{array}{c}\text { h- } \\
\text { index }\end{array}$ & C3PO & $\begin{array}{c}\text { PI- } \\
\text { BETA }\end{array}$ & Eigenfactor & Immediacy & $\begin{array}{c}\text { Article } \\
\text { Influence }\end{array}$ & CAI & $\begin{array}{c}\text { H- } \\
\text { STAR }\end{array}$ & $\begin{array}{l}\text { 2Y- } \\
\text { STAR }\end{array}$ & $\begin{array}{c}\text { Harmonic } \\
\text { Mean }\end{array}$ \\
\hline \multicolumn{15}{|c|}{ Chemistry, Multidisciplinary (127) } \\
\hline Chemical Reviews & 23.592 & 23.360 & 28.577 & 1.010 & 377 & 193.76 & 0.0387 & 0.20288 & 3.635 & 11.136 & 10.705 & 100 & 100 & 1 \\
\hline $\begin{array}{l}\text { Chemical Society } \\
\text { Reviews }\end{array}$ & 17.419 & 17.260 & 17.730 & 1.009 & 149 & 53.35 & 0.1288 & 0.05403 & 3.668 & 6.382 & 5.560 & 100 & 100 & 3 \\
\hline $\begin{array}{l}\text { Accounts of Chemical } \\
\text { Research }\end{array}$ & 12.176 & 12.104 & 15.403 & 1.006 & 224 & 96.26 & 0.0371 & 0.07275 & 2.683 & 5.925 & 5.705 & 100 & 100 & 2 \\
\hline $\begin{array}{l}\text { Angewandte Chemie - } \\
\text { International Edition }\end{array}$ & 10.879 & 9.249 & 11.025 & 1.176 & 133 & 20.06 & 0.1304 & 0.51386 & 2.657 & 3.338 & 2.903 & 80 & 72 & 5 \\
\hline Nano Letters & 10.371 & 9.491 & 12.189 & 1.093 & 162 & 34.17 & 0.0869 & 0.25290 & 1.524 & 4.492 & 4.102 & 88 & 84 & 4 \\
\hline Advanced Materials & 8.191 & 7.631 & 10.231 & 2.752 & 207 & 40.62 & 0.0988 & 0.21353 & 0.957 & 3.547 & 3.196 & 92 & 88 & 6 \\
\hline \multicolumn{15}{|l|}{ Ecology (124) } \\
\hline $\begin{array}{l}\text { Bulletin of the } \\
\text { American Museum of } \\
\text { Natural History }\end{array}$ & 16.692 & 16.462 & 4.740 & 1.014 & 18 & 7.38 & 0.4421 & 0.00287 & 1.444 & 1.772 & 0.989 & 94 & 98 & 3 \\
\hline $\begin{array}{l}\text { Trends in Ecology \& } \\
\text { Evolution }\end{array}$ & 11.904 & 11.557 & 17.188 & 1.030 & 182 & 41.06 & 0.1397 & 0.06469 & 1.913 & 7.846 & 6.750 & 98 & 96 & 2 \\
\hline $\begin{array}{l}\text { Annual Review of } \\
\text { Ecology Evolution and } \\
\text { Systematics }\end{array}$ & 10.161 & 10.000 & 17.176 & 1.016 & 53 & 51.16 & 0.0619 & 0.02416 & 0.133 & 8.322 & 7.807 & 100 & 98 & 1 \\
\hline Ecology Letters & 9.392 & 8.831 & 9.342 & 1.064 & 89 & 30.81 & 0.0885 & 0.06570 & 1.291 & 4.431 & 4.039 & 92 & 90 & 5 \\
\hline $\begin{array}{l}\text { Global Change } \\
\text { Biology }\end{array}$ & 5.876 & 5.216 & 6.709 & 1.127 & 92 & 25.39 & 0.0765 & 0.05630 & 0.866 & 2.864 & 2.645 & 80 & 78 & 6 \\
\hline Molecular Ecology & 5.325 & 4.129 & 5.966 & 1.290 & 115 & 27.75 & 0.0680 & 0.06926 & 1.506 & 1.811 & 1.688 & 68 & 56 & 4 \\
\hline
\end{tabular}




\begin{tabular}{|c|c|c|c|c|c|c|c|c|c|c|c|c|c|c|}
\hline Journal & 2YIF & 2YIF* & $5 Y I F$ & IFI & $\begin{array}{c}\text { h- } \\
\text { index }\end{array}$ & CЗPO & $\begin{array}{c}\text { PI- } \\
\text { BETA }\end{array}$ & Eigenfactor & Immediacy & $\begin{array}{c}\text { Article } \\
\text { Influence }\end{array}$ & CAI & $\begin{array}{c}\text { H- } \\
\text { STAR } \\
\end{array}$ & $\begin{array}{c}\text { 2Y- } \\
\text { STAR } \\
\end{array}$ & $\begin{array}{c}\text { Harmonic } \\
\text { Mean }\end{array}$ \\
\hline \multicolumn{15}{|c|}{ Engineering, Multidisciplinary (67) } \\
\hline $\begin{array}{l}\text { International Journal of } \\
\text { Nonlinear Sciences and } \\
\text { Numerical Simulation }\end{array}$ & 8.479 & 7.859 & 5.916 & 1.079 & 38 & 8.32 & 0.3355 & 0.01187 & 0.382 & 1.739 & 1.155 & 86 & 86 & 1 \\
\hline $\begin{array}{l}\text { CMES - Computer } \\
\text { Modeling in } \\
\text { Engineering \& Sciences }\end{array}$ & 4.785 & 1.127 & 3.656 & 4.246 & 32 & 7.96 & 0.1820 & 0.00406 & 1.306 & 0.474 & 0.388 & -38 & -52 & 6 \\
\hline Nanotechnology & 3.446 & 3.061 & 3.727 & 1.126 & 74 & 8.87 & 0.2082 & 0.09885 & 0.507 & 1.233 & 0.976 & 82 & 78 & 2 \\
\hline $\begin{array}{l}\text { International Journal } \\
\text { for Numerical Methods } \\
\text { in Engineering }\end{array}$ & 2.229 & 1.831 & 2.303 & 1.217 & 88 & 14.15 & 0.1261 & 0.03278 & 0.399 & 0.998 & 0.872 & 76 & 66 & 5 \\
\hline $\begin{array}{l}\text { Archives of } \\
\text { Computational Methods } \\
\text { in Engineering }\end{array}$ & 2.227 & 2.227 & 2.100 & 1.000 & 16 & 8.84 & 0.2500 & 0.00070 & 0.385 & 0.790 & 0.593 & 98 & 100 & 3 \\
\hline Combustion and Flame & 2.160 & 1.630 & 2.657 & 1.325 & 78 & 16.35 & 0.1045 & 0.01536 & 0.436 & 0.856 & 0.767 & 82 & 52 & 4 \\
\hline \multicolumn{15}{|c|}{ Environmental Sciences (163) } \\
\hline $\begin{array}{l}\text { Critical Reviews in } \\
\text { Environmental Science } \\
\text { and Technology }\end{array}$ & 7.409 & 7.364 & 6.097 & 1.006 & 43 & 27.60 & 0.1455 & 0.00257 & 0.273 & 1.871 & 1.599 & 100 & 100 & 1 \\
\hline $\begin{array}{l}\text { Environmental Health } \\
\text { Perspectives }\end{array}$ & 6.123 & 5.576 & 7.069 & 1.098 & 140 & 18.57 & 0.3106 & 0.06530 & 0.897 & 2.000 & 1.379 & 88 & 84 & 2 \\
\hline Global Change Biology & 5.876 & 5.216 & 6.709 & 1.127 & 92 & 25.39 & 0.0765 & 0.05630 & 0.866 & 2.864 & 2.645 & 80 & 78 & 4 \\
\hline $\begin{array}{l}\text { Frontiers in Ecology } \\
\text { and the Environment }\end{array}$ & 5.065 & 4.676 & 5.926 & 1.083 & 43 & 4.42 & 0.6927 & 0.01551 & 1.286 & 2.733 & 0.840 & 90 & 86 & 6 \\
\hline Conservation Biology & 4.705 & 4.243 & 5.393 & 1.109 & 123 & 27.26 & 0.1240 & 0.03918 & 0.500 & 2.073 & 1.816 & 92 & 82 & 5 \\
\hline $\begin{array}{l}\text { Annual Reviews of } \\
\text { Environment and } \\
\text { Resources }\end{array}$ & 4.667 & 4.467 & 6.726 & 1.045 & 24 & 16.81 & 0.2034 & 0.00556 & 0.050 & 3.438 & 2.739 & 96 & 92 & 3 \\
\hline
\end{tabular}




\begin{tabular}{|c|c|c|c|c|c|c|c|c|c|c|c|c|c|c|}
\hline Journal & 2YIF & 2 YIF* $^{*}$ & 5YIF & IFI & $\begin{array}{c}\text { h- } \\
\text { index }\end{array}$ & СЗРО & $\begin{array}{c}\text { PI- } \\
\text { BETA }\end{array}$ & Eigenfactor & Immediacy & $\begin{array}{c}\text { Article } \\
\text { Influence }\end{array}$ & CAI & $\begin{array}{c}\text { H- } \\
\text { STAR }\end{array}$ & $\begin{array}{c}\text { 2Y- } \\
\text { STAR }\end{array}$ & $\begin{array}{c}\text { Harmonic } \\
\text { Mean }\end{array}$ \\
\hline \multicolumn{15}{|c|}{ Geosciences, Multidisciplinary (144) } \\
\hline Earth-Science Reviews & 6.558 & 6.442 & 6.814 & 1.018 & 74 & 31.56 & 0.1142 & 0.01475 & 0.689 & 3.096 & 2.743 & 98 & 98 & 2 \\
\hline $\begin{array}{l}\text { Annual Review of } \\
\text { Earth and Planetary } \\
\text { Sciences }\end{array}$ & 6.364 & 6.295 & 9.040 & 1.011 & 80 & 54.19 & 0.0713 & 0.01443 & 1.368 & 6.447 & 5.988 & 100 & 98 & 1 \\
\hline $\begin{array}{l}\text { Global Biogeochemical } \\
\text { Cycles }\end{array}$ & 4.090 & 3.638 & 4.993 & 1.124 & 99 & 32.22 & 0.0596 & 0.03088 & 0.739 & 2.538 & 2.387 & 84 & 78 & 3 \\
\hline Precambrian Research & 3.736 & 2.534 & 3.912 & 1.474 & 78 & 20.68 & 0.0945 & 0.01460 & 1.401 & 1.257 & 1.138 & 42 & 36 & 4 \\
\hline Gondwana Research & 3.728 & 2.156 & 2.691 & 1.729 & 31 & 6.06 & 0.2124 & 0.00569 & 2.126 & 0.742 & 0.584 & 22 & 16 & 5 \\
\hline $\begin{array}{l}\text { Geotextiles and } \\
\text { Geomembranes }\end{array}$ & 3.701 & 1.567 & 3.063 & 2.362 & 23 & 5.37 & 0.3012 & 0.00174 & 0.600 & 0.553 & 0.386 & 14 & -14 & 6 \\
\hline \multicolumn{15}{|c|}{ Materials Sciences, Multidisciplinary (192) } \\
\hline Nature Materials & 23.132 & 22.721 & 25.759 & 1.018 & 142 & 37.45 & 0.3415 & 0.18554 & 5.326 & 12.608 & 8.303 & 98 & 98 & 1 \\
\hline $\begin{array}{l}\text { Nature } \\
\text { Nanotechnology }\end{array}$ & 20.571 & 19.756 & 20.588 & 1.041 & 62 & 17.44 & 0.2773 & 0.02936 & 5.097 & 11.131 & 8.045 & 90 & 94 & 4 \\
\hline $\begin{array}{l}\text { Progress in Materials } \\
\text { Science }\end{array}$ & 18.132 & 18.000 & 17.263 & 1.007 & 66 & 80.34 & 0.1102 & 0.01283 & 1.929 & 7.235 & 6.437 & 100 & 100 & 2 \\
\hline $\begin{array}{l}\text { Materials Science \& } \\
\text { Engineering R-Reports }\end{array}$ & 12.619 & 12.524 & 20.328 & 1.008 & 82 & 101.92 & 0.9731 & 0.01107 & 1.062 & 8.192 & 0.220 & 100 & 100 & 3 \\
\hline Nano Letters & 10.371 & 9.491 & 12.189 & 1.093 & 162 & 34.17 & 0.0869 & 0.25290 & 1.524 & 4.492 & 4.102 & 88 & 84 & 5 \\
\hline Advanced Materials & 8.191 & 7.631 & 10.231 & 1.073 & 207 & 40.62 & 0.0988 & 0.21353 & 0.957 & 3.547 & 3.196 & 92 & 88 & 6 \\
\hline
\end{tabular}




\begin{tabular}{|c|c|c|c|c|c|c|c|c|c|c|c|c|c|c|}
\hline Journal & 2YIF & 2YIF* & 5YIF & IFI & $\begin{array}{c}\text { h- } \\
\text { index }\end{array}$ & С3PO & $\begin{array}{c}\text { PI- } \\
\text { BETA }\end{array}$ & Eigenfactor & Immediacy & $\begin{array}{c}\text { Article } \\
\text { Influence }\end{array}$ & CAI & $\begin{array}{c}\text { H- } \\
\text { STAR }\end{array}$ & $\begin{array}{l}\text { 2Y- } \\
\text { STAR }\end{array}$ & $\begin{array}{c}\text { Harmonic } \\
\text { Mean }\end{array}$ \\
\hline \multicolumn{15}{|l|}{ Mathematics (215) } \\
\hline $\begin{array}{l}\text { Communications on } \\
\text { Pure and Applied } \\
\text { Mathematics }\end{array}$ & 3.806 & 3.677 & 3.855 & 1.035 & 71 & 27.12 & 0.1159 & 0.02065 & 0.774 & 3.757 & 3.322 & 98 & 94 & 1 \\
\hline $\begin{array}{l}\text { Bulletin of the } \\
\text { American Mathematical } \\
\text { Society }\end{array}$ & 3.500 & 3.400 & 3.658 & 1.029 & 44 & 17.30 & 0.1395 & 0.00539 & 0.211 & 3.334 & 2.869 & 100 & 96 & 6 \\
\hline Annals of Mathematics & 3.447 & 3.372 & 3.575 & 1.022 & 71 & 24.23 & 0.0634 & 0.02645 & 1.024 & 4.487 & 4.203 & 98 & 96 & 2 \\
\hline $\begin{array}{l}\text { Journal of American } \\
\text { Mathematical Society }\end{array}$ & 2.476 & 2.397 & 3.308 & 1.033 & 44 & 19.35 & 0.0782 & 0.01613 & 0.256 & 4.666 & 4.301 & 98 & 94 & 5 \\
\hline $\begin{array}{l}\text { Memoirs of the } \\
\text { American Mathematical } \\
\text { Society }\end{array}$ & 2.367 & 2.367 & 2.109 & 1.000 & 10 & 1.01 & 0.7678 & 0.00742 & 0.571 & 2.594 & 0.602 & 100 & 100 & 4 \\
\hline $\begin{array}{l}\text { Inventiones } \\
\text { Mathematicae }\end{array}$ & 2.287 & 2.250 & 2.375 & 1.016 & 74 & 19.41 & 0.0566 & 0.02498 & 0.420 & 3.354 & 3.164 & 98 & 98 & 3 \\
\hline \multicolumn{15}{|c|}{ Mathematics, Applied (175) } \\
\hline $\begin{array}{l}\text { International Journal of } \\
\text { Nonlinear Sciences and } \\
\text { Numerical Simulation }\end{array}$ & 8.479 & 7.859 & 5.916 & 1.079 & 38 & 8.32 & 0.3355 & 0.01187 & 0.382 & 1.739 & 1.155 & 86 & 86 & 3 \\
\hline $\begin{array}{l}\text { Communications on } \\
\text { Pure and Applied } \\
\text { Mathematics }\end{array}$ & 3.806 & 3.677 & 3.855 & 1.035 & 71 & 27.12 & 0.1159 & 0.02065 & 0.774 & 3.757 & 3.322 & 98 & 94 & 1 \\
\hline SIAM Review & 2.739 & 2.717 & 8.235 & 1.008 & 73 & 24.02 & 0.4170 & 0.01179 & 0.773 & 4.624 & 2.696 & 100 & 100 & 2 \\
\hline $\begin{array}{l}\text { Applied and } \\
\text { Computational } \\
\text { Harmonic Analysis }\end{array}$ & 2.344 & 2.042 & 2.635 & 1.148 & 40 & 13.52 & 0.1771 & 0.00740 & 0.262 & 1.845 & 1.518 & 82 & 76 & 5 \\
\hline $\begin{array}{l}\text { Mathematical } \\
\text { Programming }\end{array}$ & 2.336 & 2.147 & 2.745 & 1.088 & 68 & 16.58 & 0.1165 & 0.01722 & 0.589 & 1.886 & 1.666 & 90 & 86 & 4 \\
\hline $\begin{array}{l}\text { Mathematical Models } \\
\text { \& Methods in Applied } \\
\text { Sciences }\end{array}$ & 2.333 & 2.007 & 1.872 & 1.162 & 33 & 6.91 & 0.1966 & 0.00868 & 0.630 & 1.041 & 0.836 & 82 & 72 & 6 \\
\hline
\end{tabular}




\begin{tabular}{|c|c|c|c|c|c|c|c|c|c|c|c|c|c|c|}
\hline Journal & 2YIF & 2 YIF* $^{*}$ & 5YIF & IFI & $\begin{array}{c}\text { h- } \\
\text { index }\end{array}$ & CЗPO & $\begin{array}{c}\text { PI- } \\
\text { BETA }\end{array}$ & Eigenfactor & Immediacy & $\begin{array}{c}\text { Article } \\
\text { Influence }\end{array}$ & CAI & $\begin{array}{l}\text { H- } \\
\text { STAR }\end{array}$ & $\begin{array}{l}\text { 2Y- } \\
\text { STAR }\end{array}$ & $\begin{array}{c}\text { Harmonic } \\
\text { Mean } \\
\text { ranking }\end{array}$ \\
\hline \multicolumn{15}{|c|}{ Medicine, General \& Internal (107) } \\
\hline $\begin{array}{l}\text { New England Journal } \\
\text { of Medicine }\end{array}$ & 50.017 & 49.212 & 49.911 & 1.016 & 227 & 22.38 & 0.4712 & 0.68029 & 12.225 & 18.763 & 9.921 & 100 & 98 & 1 \\
\hline $\begin{array}{l}\text { JAMA - Journal of the } \\
\text { American Medical } \\
\text { Association }\end{array}$ & 31.718 & 31.022 & 27.957 & 1.022 & 175 & 15.56 & 0.5322 & 0.38098 & 7.556 & 11.148 & 5.215 & 98 & 96 & 2 \\
\hline Lancet & 28.409 & 27.294 & 27.264 & 1.041 & 156 & 12.83 & 0.4921 & 0.41177 & 8.505 & 9.946 & 5.051 & 98 & 94 & 4 \\
\hline $\begin{array}{l}\text { Annals of Internal } \\
\text { Medicine }\end{array}$ & 17.457 & 16.798 & 16.117 & 1.039 & 214 & 29.00 & 0.3861 & 0.12604 & 4.574 & 6.270 & 3.849 & 98 & 94 & 3 \\
\hline British Medical Journal & 12.857 & 12.175 & 10.665 & 1.056 & 31 & 1.11 & 0.7282 & 0.15945 & 6.032 & 3.789 & 1.030 & 96 & 90 & 6 \\
\hline PLOS Medicine & 12.185 & 11.904 & 13.180 & 1.024 & 58 & 12.42 & 0.2069 & 0.05742 & 3.684 & 6.139 & 4.869 & 94 & 96 & 5 \\
\hline \multicolumn{15}{|c|}{ Multidisciplinary Sciences (42) } \\
\hline Nature & 31.434 & 30.865 & 31.210 & 1.018 & 149 & 15.18 & 0.4679 & 1.76345 & 8.194 & 17.279 & 9.194 & 100 & 98 & 1 \\
\hline Science & 28.103 & 27.551 & 30.268 & 1.020 & 132 & 13.74 & 0.4226 & 1.58309 & 6.261 & 16.286 & 9.404 & 100 & 98 & 2 \\
\hline $\begin{array}{l}\text { Proceedings of the } \\
\text { National Academy of } \\
\text { Sciences of the Unites } \\
\text { States of America } \\
\text { (PNAS) }\end{array}$ & 9.380 & 9.025 & 10.228 & 1.039 & 31 & 3.23 & 0.3689 & 1.69817 & 1.635 & 4.847 & 3.059 & 96 & 94 & 5 \\
\hline Nano Today & 8.795 & 8.769 & 9.231 & 1.003 & 23 & 4.61 & 0.6848 & 0.00283 & 1.077 & 3.278 & 1.033 & 100 & 100 & 3 \\
\hline $\begin{array}{l}\text { IBM Journal of } \\
\text { Research and } \\
\text { Development }\end{array}$ & 3.722 & 3.577 & 3.385 & 1.041 & 62 & 16.86 & 0.1706 & 0.00836 & 1.118 & 1.440 & 1.194 & 94 & 94 & 4 \\
\hline $\begin{array}{l}\text { Journal of the Royal } \\
\text { Society Interface }\end{array}$ & 3.621 & 3.249 & 3.908 & 1.114 & 27 & 6.63 & 0.1880 & 0.00787 & 1.117 & 1.486 & 1.207 & 80 & 80 & 6 \\
\hline
\end{tabular}




\begin{tabular}{|c|c|c|c|c|c|c|c|c|c|c|c|c|c|c|}
\hline Journal & 2YIF & 2YIF* & 5YIF & IFI & $\begin{array}{c}\text { h- } \\
\text { index }\end{array}$ & СЗРО & $\begin{array}{c}\text { PI- } \\
\text { BETA }\end{array}$ & Eigenfactor & Immediacy & $\begin{array}{c}\text { Article } \\
\text { Influence }\end{array}$ & CAI & $\begin{array}{l}\text { H- } \\
\text { STAR }\end{array}$ & $\begin{array}{l}\text { 2Y- } \\
\text { STAR }\end{array}$ & $\begin{array}{l}\text { Harmonic } \\
\text { Mean } \\
\text { ranking } \\
\end{array}$ \\
\hline \multicolumn{15}{|l|}{ Neurosciences (221) } \\
\hline $\begin{array}{l}\text { Annual Review of } \\
\text { Neuroscience }\end{array}$ & 26.405 & 26.190 & 31.209 & 1.008 & 183 & 235.21 & 0.0020 & 0.04611 & 3.348 & 18.915 & 18.876 & 100 & 100 & 1 \\
\hline $\begin{array}{l}\text { Nature Reviews } \\
\text { Neuroscience }\end{array}$ & 25.940 & 25.497 & 27.678 & 1.017 & 169 & 42.11 & 0.5779 & 0.11399 & 4.859 & 13.939 & 5.883 & 98 & 98 & 3 \\
\hline Neuron & 14.170 & 13.370 & 14.857 & 1.060 & 325 & 96.62 & 0.0700 & 0.28702 & 2.599 & 8.296 & 7.715 & 92 & 90 & 2 \\
\hline Nature Neuroscience & 14.164 & 13.841 & 16.825 & 1.023 & 201 & 56.18 & 0.1541 & 0.19666 & 3.297 & 9.120 & 7.714 & 98 & 96 & 5 \\
\hline $\begin{array}{l}\text { Behavioural and Brain } \\
\text { Sciences }\end{array}$ & 12.818 & 11.318 & 19.355 & 1.133 & 109 & 5.22 & 0.5657 & 0.01173 & 2.667 & 8.533 & 3.706 & 92 & 78 & 6 \\
\hline $\begin{array}{l}\text { Trends in } \\
\text { Neurosciences }\end{array}$ & 12.817 & 12.640 & 14.475 & 1.014 & 234 & 80.18 & 0.1048 & 0.06325 & 1.925 & 6.910 & 6.186 & 100 & 98 & 4 \\
\hline \multicolumn{15}{|c|}{ Operations Research \& Management (64) } \\
\hline $\begin{array}{l}\text { Expert Systems with } \\
\text { Applications }\end{array}$ & 2.596 & 1.940 & 2.638 & 1.338 & 39 & 3.93 & 0.3960 & 0.00588 & 0.524 & 0.354 & 0.214 & 52 & 50 & 6 \\
\hline $\begin{array}{l}\text { Journal of Operations } \\
\text { Management }\end{array}$ & 2.420 & 2.023 & 3.814 & 1.196 & 46 & 16.82 & 0.0934 & 0.00494 & 0.364 & 0.966 & 0.876 & 72 & 68 & 4 \\
\hline Management Science & 2.354 & 2.080 & 4.065 & 1.132 & 118 & 28.62 & 0.1032 & 0.03318 & 0.389 & 2.317 & 2.078 & 94 & 78 & 1 \\
\hline $\begin{array}{l}\text { Mathematical } \\
\text { Programming }\end{array}$ & 2.336 & 2.147 & 2.745 & 1.088 & 68 & 16.58 & 0.1165 & 0.01722 & 0.589 & 1.886 & 1.666 & 90 & 84 & 2 \\
\hline $\begin{array}{l}\text { Omega-International } \\
\text { Journal of } \\
\text { Management Science }\end{array}$ & 2.175 & 1.939 & 2.367 & 1.122 & 45 & 9.42 & 0.1733 & 0.00389 & 0.736 & 0.700 & 0.579 & 88 & 80 & 5 \\
\hline $\begin{array}{l}\text { Systems \& Control } \\
\text { Letters }\end{array}$ & 2.073 & 1.955 & 2.620 & 1.060 & 73 & 13.62 & 0.1724 & 0.01377 & 0.235 & 1.147 & 0.949 & 90 & 90 & 3 \\
\hline
\end{tabular}




\begin{tabular}{|c|c|c|c|c|c|c|c|c|c|c|c|c|c|c|}
\hline Journal & 2YIF & 2YIF* & 5YIF & IFI & $\begin{array}{c}\text { h- } \\
\text { index }\end{array}$ & СЗРО & $\begin{array}{c}\text { PI- } \\
\text { BETA }\end{array}$ & Eigenfactor & Immediacy & $\begin{array}{c}\text { Article } \\
\text { Influence }\end{array}$ & CAI & $\begin{array}{l}\text { H- } \\
\text { STAR }\end{array}$ & $\begin{array}{l}\text { 2Y- } \\
\text { STAR }\end{array}$ & $\begin{array}{c}\text { Harmonic } \\
\text { Mean } \\
\text { ranking } \\
\end{array}$ \\
\hline \multicolumn{15}{|c|}{ Physics, Multidisciplinary (68) } \\
\hline $\begin{array}{l}\text { Reviews of Modern } \\
\text { Physics }\end{array}$ & 33.985 & 33.785 & 40.395 & 1.006 & 205 & 201.07 & 0.0488 & 0.08932 & 7.028 & 24.877 & 23.664 & 100 & 100 & 1 \\
\hline $\begin{array}{l}\text { Physics Reports - Review } \\
\text { Section of Physics Letters }\end{array}$ & 18.522 & 18.357 & 16.368 & 1.009 & 183 & 69.75 & 0.1128 & 0.05770 & 3.959 & 8.060 & 7.151 & 98 & 100 & 3 \\
\hline Nature Physics & 16.821 & 16.442 & 17.189 & 1.023 & 65 & 14.98 & 0.3898 & 0.07468 & 4.793 & 12.715 & 7.759 & 94 & 96 & 4 \\
\hline $\begin{array}{l}\text { Reports on Progress in } \\
\text { Physics }\end{array}$ & 12.090 & 12.034 & 12.450 & 1.005 & 129 & 74.12 & 0.0610 & 0.03287 & 2.735 & 6.651 & 6.245 & 100 & 100 & 2 \\
\hline Physical Review Letters & 7.180 & 6.387 & 7.134 & 1.124 & 61 & 6.78 & 0.2096 & 1.28160 & 1.974 & 3.298 & 2.607 & 86 & 78 & 5 \\
\hline Soft Matter & 4.586 & 4.136 & 4.890 & 1.109 & 37 & 5.84 & 0.3062 & 0.01441 & 0.834 & 1.994 & 1.383 & 82 & 82 & 6 \\
\hline \multicolumn{15}{|l|}{ Psychiatry (101) } \\
\hline $\begin{array}{l}\text { Archives of General } \\
\text { Psychiatry }\end{array}$ & 14.273 & 13.795 & 17.272 & 1.035 & 253 & 81.53 & 0.1285 & 0.08916 & 2.197 & 6.705 & 5.844 & 98 & 94 & 1 \\
\hline Molecular Psychiatry & 12.537 & 11.932 & 11.937 & 1.051 & 102 & 25.48 & 0.2115 & 0.04612 & 4.161 & 4.247 & 3.349 & 92 & 92 & 3 \\
\hline $\begin{array}{l}\text { American Journal of } \\
\text { Psychiatry }\end{array}$ & 10.545 & 10.202 & 10.806 & 1.034 & 189 & 26.14 & 0.3815 & 0.10924 & 3.113 & 3.657 & 2.262 & 98 & 94 & 2 \\
\hline Biological Psychiatry & 8.672 & 8.305 & 9.015 & 1.044 & 114 & 9.25 & 0.6735 & 0.11389 & 1.943 & 3.186 & 1.040 & 94 & 92 & 4 \\
\hline Neuropsychopharmacology & 6.835 & 6.444 & 6.716 & 1.061 & 116 & 16.51 & 0.4399 & 0.05970 & 2.106 & 2.164 & 1.212 & 92 & 90 & 5 \\
\hline Schizophrenia Bulletin & 6.592 & 5.959 & 6.333 & 1.106 & 116 & 11.76 & 0.6422 & 0.01794 & 1.372 & 2.107 & 0.754 & 88 & 82 & 6 \\
\hline
\end{tabular}




\begin{tabular}{|c|c|c|c|c|c|c|c|c|c|c|c|c|c|c|}
\hline Journal & 2YIF & 2YIF* & 5YIF & IFI & $\begin{array}{c}\text { h- } \\
\text { index }\end{array}$ & СЗРО & $\begin{array}{c}\text { PI- } \\
\text { BETA }\end{array}$ & Eigenfactor & Immediacy & $\begin{array}{c}\text { Article } \\
\text { Influence }\end{array}$ & CAI & $\begin{array}{c}\text { H- } \\
\text { STAR }\end{array}$ & $\begin{array}{c}\text { 2Y- } \\
\text { STAR }\end{array}$ & $\begin{array}{c}\text { Harmonic } \\
\text { Mean } \\
\text { ranking }\end{array}$ \\
\hline
\end{tabular}

Public, Environmental \& Occupational Health (105)

\begin{tabular}{|c|c|c|c|c|c|c|c|c|c|c|c|c|c|c|}
\hline $\begin{array}{l}\text { Epidemiologic } \\
\text { Reviews }\end{array}$ & 12.130 & 12.130 & 10.039 & 1.000 & 79 & 56.04 & 0.0271 & 0.00454 & 0.200 & 4.020 & 3.911 & 82 & 100 & 1 \\
\hline $\begin{array}{l}\text { Environmental Health } \\
\text { Perspectives }\end{array}$ & 6.123 & 5.576 & 7.069 & 1.098 & 140 & 18.57 & 0.3106 & 0.06530 & 0.897 & 2.000 & 1.379 & 88 & 84 & 4 \\
\hline $\begin{array}{l}\text { Annual Review of } \\
\text { Public Health }\end{array}$ & 6.045 & 5.864 & 7.491 & 1.031 & 74 & 40.94 & 0.0436 & 0.00780 & 1.680 & 3.088 & 2.953 & 98 & 94 & 2 \\
\hline $\begin{array}{l}\text { International Journal of } \\
\text { Epidemiology }\end{array}$ & 5.838 & 5.548 & 5.845 & 1.052 & 101 & 18.42 & 0.1378 & 0.03685 & 2.060 & 2.527 & 2.179 & 94 & 92 & 3 \\
\hline $\begin{array}{l}\text { American Journal of } \\
\text { Epidemiology }\end{array}$ & 5.454 & 5.157 & 6.404 & 1.058 & 102 & 7.72 & 0.6544 & 0.07700 & 1.258 & 2.587 & 0.894 & 94 & 90 & 5 \\
\hline Epidemiology & 5.406 & 4.872 & 5.705 & 1.110 & 77 & 3.73 & 0.7831 & 0.02219 & 1.645 & 2.139 & 1.675 & 90 & 82 & 6 \\
\hline
\end{tabular}

\section{Statistics \& Probability (92)}

\begin{tabular}{|c|c|c|c|c|c|c|c|c|c|c|c|c|c|c|}
\hline Econometrica & 3.865 & 3.606 & 4.943 & 1.072 & 123 & 49.81 & 0.0766 & 0.04527 & 0.255 & 7.243 & 6.688 & 98 & 98 & 1 \\
\hline Biostatistics & 3.394 & 3.232 & 5.253 & 1.050 & 26 & 14.57 & 0.2062 & 0.01528 & 0.643 & 3.011 & 2.390 & 96 & 92 & 2 \\
\hline $\begin{array}{l}\text { Journal of the Royal } \\
\text { Statistical Society } \\
\text { Series B-Statistical } \\
\text { Methodology }\end{array}$ & 2.835 & 2.729 & 3.943 & 1.039 & 52 & 22.46 & 0.1364 & 0.01756 & 0.551 & 3.476 & 3.002 & 100 & 94 & 3 \\
\hline $\begin{array}{l}\text { Annals of Applied } \\
\text { Statistics }\end{array}$ & 2.448 & 2.034 & 2.483 & 1.204 & 9 & 2.57 & 0.4634 & 0.00104 & 0.403 & 1.615 & 0.867 & 44 & 68 & 4 \\
\hline $\begin{array}{l}\text { Journal of the } \\
\text { American Statistical } \\
\text { Association }\end{array}$ & 2.394 & 2.187 & 3.462 & 1.095 & 126 & 27.49 & 0.1740 & 0.03673 & 0.187 & 3.013 & 2.489 & 94 & 84 & 5 \\
\hline Annals of Statistics & 2.307 & 1.965 & 3.094 & 1.174 & 93 & 21.29 & 0.1274 & 0.03110 & 0.614 & 2.998 & 2.616 & 90 & 72 & 6 \\
\hline
\end{tabular}




\begin{tabular}{|l|c|c|c|c|c|c|c|c|c|c|c|c|}
\hline Journal & 2YIF & 2YIF* & 5YIF & IFI & $\begin{array}{c}\text { h- } \\
\text { index }\end{array}$ & C3PO & $\begin{array}{c}\text { PI- } \\
\text { BETA }\end{array}$ & Eigenfactor & $\begin{array}{c}\text { Immediacy } \\
\text { Influence }\end{array}$ & $\begin{array}{c}\text { Article } \\
\text { CAI } \\
\text { STAR }\end{array}$ & $\begin{array}{c}\text { 2Y- } \\
\text { STAR }\end{array}$ & $\begin{array}{c}\text { Harmonic } \\
\text { Mean } \\
\text { ranking }\end{array}$ \\
\hline
\end{tabular}

\section{Surgery (148)}

\begin{tabular}{|c|c|c|c|c|c|c|c|c|c|c|c|c|c|c|}
\hline Annals of Surgery & 8.460 & 7.902 & 9.776 & 1.071 & 186 & 36.58 & 0.2401 & 0.06729 & 1.064 & 2.699 & 2.051 & 94 & 88 & 1 \\
\hline $\begin{array}{l}\text { American Journal of } \\
\text { Transplantation }\end{array}$ & 6.559 & 5.771 & 6.281 & 1.137 & 56 & 2.82 & 0.7561 & 0.06431 & 1.213 & 1.868 & 0.456 & 80 & 76 & 5 \\
\hline Endoscopy & 6.091 & 5.011 & 5.268 & 1.216 & 78 & 10.76 & 0.2563 & 0.02344 & 1.451 & 1.265 & 0.941 & 80 & 66 & 4 \\
\hline $\begin{array}{l}\text { British Journal of } \\
\text { Surgery }\end{array}$ & 4.921 & 4.603 & 5.108 & 1.069 & 100 & 8.93 & 0.5670 & 0.03337 & 0.806 & 1.423 & 0.616 & 96 & 88 & 6 \\
\hline $\begin{array}{l}\text { Journal of Neurology, } \\
\text { Neurosurgery and } \\
\text { Psychiatry }\end{array}$ & 4.622 & 4.477 & 4.248 & 1.032 & 107 & 12.45 & 0.3564 & 0.04595 & 1.070 & 1.323 & 0.851 & 96 & 94 & 2 \\
\hline Archives of Surgery & 4.259 & 4.089 & 4.556 & 1.042 & 120 & 18.23 & 0.3254 & 0.02484 & 0.673 & 1.317 & 0.888 & 98 & 92 & 3 \\
\hline
\end{tabular}

\section{Zoology (125)}

\begin{tabular}{|c|c|c|c|c|c|c|c|c|c|c|c|c|c|c|}
\hline Wildlife Monographs & 4.250 & 4.000 & 4.444 & 1.063 & 21 & 25.82 & 0.1250 & 0.00073 & 0.000 & 1.837 & \#REF! & 94 & 90 & 3 \\
\hline $\begin{array}{l}\text { Journal of Animal } \\
\text { Ecology }\end{array}$ & 4.220 & 3.918 & 4.792 & 1.077 & 104 & 32.16 & 0.0654 & 0.02795 & 0.729 & 2.095 & 1.958 & 92 & 86 & 1 \\
\hline $\begin{array}{l}\text { Journal of Comparative } \\
\text { Neurology }\end{array}$ & 3.743 & 3.262 & 3.944 & 1.147 & 185 & 36.34 & 0.0394 & 0.06616 & 0.971 & 1.489 & 1.430 & 82 & 76 & 2 \\
\hline $\begin{array}{l}\text { Journal of } \\
\text { Experimental Zoology } \\
\text { Part B-Molecular and } \\
\text { Developmental } \\
\text { Evolution }\end{array}$ & 3.364 & 3.178 & 3.227 & 1.059 & 28 & 8.30 & 0.1696 & 0.00674 & 0.633 & 1.328 & 1.103 & 88 & 90 & 4 \\
\hline Behavioural Ecology & 3.224 & 2.844 & 3.726 & 1.134 & 71 & 20.34 & 0.0819 & 0.02100 & 0.495 & 1.366 & 1.254 & 82 & 78 & 6 \\
\hline $\begin{array}{l}\text { Behavioural Ecology } \\
\text { and Sociobiology }\end{array}$ & 2.917 & 2.561 & 3.173 & 1.139 & 89 & 24.65 & 0.0598 & 0.02141 & 0.652 & 1.178 & 1.108 & 84 & 76 & 5 \\
\hline
\end{tabular}

Note: Citations data were downloaded from ISI on 4 June 2010 for 1988-2010. 
Table 3

Correlations for 13 RAM for 112 Distinct Journals in 20 ISI Categories

\begin{tabular}{|c|c|c|c|c|c|c|c|c|c|c|c|c|c|}
\hline RAM & 2YIF & 2 YIF* $^{*}$ & 5YIF & IFI & $\begin{array}{c}\text { h- } \\
\text { index }\end{array}$ & СЗРО & $\begin{array}{c}\text { PI- } \\
\text { BETA }\end{array}$ & Eigenfactor & Immediacy & $\begin{array}{c}\text { Article } \\
\text { Influence }\end{array}$ & CAI & $\begin{array}{c}\text { H- } \\
\text { STAR }\end{array}$ & $\begin{array}{c}\text { 2Y- } \\
\text { STAR }\end{array}$ \\
\hline $2 Y I F$ & 1.000 & & & & & & & & & & & & \\
\hline 2YIF* & 0.998 & 1.000 & & & & & & & & & & & \\
\hline $5 Y I F$ & 0.967 & 0.967 & 1.000 & & & & & & & & & & \\
\hline IFI & -0.170 & -0.219 & -0.195 & 1.000 & & & & & & & & & \\
\hline h-index & 0.541 & 0.542 & 0.591 & -0.186 & 1.000 & & & & & & & & \\
\hline СЗРО & 0.467 & 0.481 & 0.554 & -0.164 & 0.588 & 1.000 & & & & & & & \\
\hline PI-BETA & 0.149 & 0.147 & 0.121 & -0.044 & -0.191 & -0.344 & 1.000 & & & & & & \\
\hline Eigenfactor & 0.426 & 0.417 & 0.406 & -0.060 & 0.173 & -0.076 & 0.137 & 1.000 & & & & & \\
\hline Immediacy & 0.880 & 0.870 & 0.838 & -0.096 & 0.447 & 0.182 & 0.232 & 0.475 & 1.000 & & & & \\
\hline $\begin{array}{l}\text { Article } \\
\text { Influence }\end{array}$ & 0.888 & 0.895 & 0.936 & -0.230 & 0.508 & 0.622 & 0.021 & 0.378 & 0.745 & 1.000 & & & \\
\hline CAI & 0.745 & 0.754 & 0.804 & -0.211 & 0.533 & 0.785 & -0.272 & 0.228 & 0.556 & 0.919 & 1.000 & & \\
\hline H-STAR & 0.274 & 0.324 & 0.313 & -0.880 & 0.282 & 0.262 & 0.058 & 0.085 & 0.167 & 0.360 & 0.326 & 1.000 & \\
\hline 2Y-STAR & 0.312 & 0.364 & 0.339 & -0.888 & 0.251 & 0.285 & 0.064 & 0.074 & 0.185 & 0.389 & 0.358 & 0.962 & 1.000 \\
\hline
\end{tabular}

Note: Citations data were downloaded from ISI on 4 June 2010 for $1988-2010$. As there is an overlap of 8 journals across the 20 ISI categories, there are 112 distinct journals. 